\title{
Development of Radar and Navigation Radar Modules As A Learning Media Radar Course And Navigation In The Department Of Electrical Engineering, UNESA
}

\author{
Farid Baskoro,S.T M.T \\ Department of Electrical Engineering, Faculty of Engineering, \\ Surabaya State University \\ Jl. Ketintang, Surabaya
}

\begin{abstract}
RADAR (Radio Detection And Ranging) is a tool used to detect and know the distance of an object. Radar is one of the important tools in the world of telecommunications, shipping and in the military world. So that the State University of Surabaya, especially the Department of Electrical Engineering education set Radar and Navigation as One of the compulsory lecture that must be taken in the field of communication electronics studies. In this study the author tries to develop teaching module to facilitate students in studying radar and navigation subjects. Where in the module consists of 7 chapters namely Radar History, Radar Type, In Flight Radar, Navigation System, Infrastructure Radar, Hadware radar, and Radar Calibration and Radar Technique. The results of this module are then validated by expert lecturers and giving a student response questionnaire. Results for module validation by expert media obtained an average score of $84.06 \%$ for student responses in an average score of $83.21 \%$. Based on the above data can be stated that the module is suitable to be used as one of the reference and can be accepted by the students.
\end{abstract}

Keywords: Radar. Radar Type, Teaching Module, Radar Infrastructure

\section{Introduction}

Education is one of the most important needs in human life. According to Smaldino (2012: 11) learning is a process of developing new knowledge, skills and behaviors that are individual interactions with information and the environment

One source of information that can be obtained is through teaching modules. With the teaching module, learners can easily understand the material content of a lesson. According Arsyad, (2013: 4), teaching module physical facilities to deliver content or learning materials such as books, movies, videos and others.

In the course of radar and navigation in the field of elekktro technical education, Unesa to facilitate the students in learning the subjects, then make a research in the form of the development of radar and navigation module. The module consists of 7 chapters. Before the module is first printed the draft module is validated by a media expert and distributed questionnaires to students whether the students feel helped by the existence of the teaching module. 


\section{Basic Theory}

\subsection{Radar History}

The name RADAR or Radio Detection And Ranging became popular during World War II. At this time the radar experienced a lot of development. After the world war after the development of radar continues to be done so that radar can be utilized in various aspects whether it is telecommunications, military, sailing, aviation and others. One of the most fenominal discoveries in the radar world is the douppler effect through the equation:

$$
\text { fpenerima }=\frac{V \pm V p}{V \pm V S} * \text { fsumber............ }
$$

where :

$\mathrm{V}=$ = the sound speed of 340 meters $/ \mathrm{sec}$

$\mathrm{Vp}=$ the speed of the listener meter / detik

Vs $\quad=$ source speed

Fpenerima $=$ frequency received by receiver $(\mathrm{Hz})$

fsumber $=$ the frequency emitted by the source (Hz.)

The invention of the douppler effect is widely used today such as Radar Gun. Radar Gun is a tool used to detect the speed of a vehicle. This tool is widely used by the police to crack down on motorists who exceed

the existing traffic speed limi In the world of radar ships can be used as a navigation tool to facilitate the captain in determining the route of fast and efficient shipping, in addition radar can also be used as a tool to detect fish through fish founder.

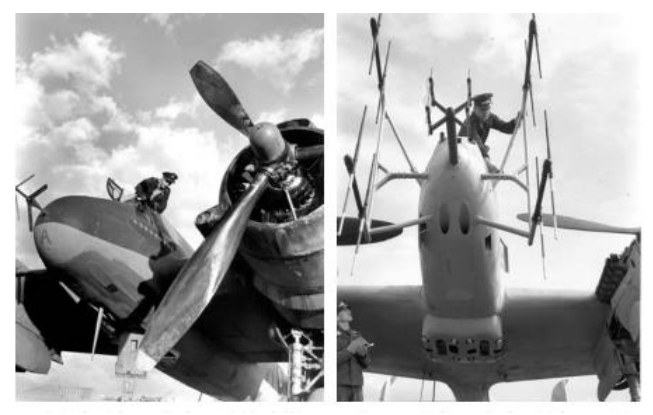

Figure 1. Use of Radar On military aircraft

\subsection{Radar In Navigation System}

The use of radar in the aviation world is very useful both for the ATC (Air Traffic Control), as well as for the pilot itself. Where radar signals will read objects that are reflected by radar signals (echo). Radar in flight is divided into 2:

a.Primary Radar: This radar system is a passive nature, in which the aircraft is not actively engaged in the exposure of RF radarsignals.

b. Secondary Radar: is an active radar where the aircraft play an active role if it receives RF radar emission. This happens because in radar peswat in complete transponder that serves to have a conversation in the form of pulses through the antenna on land.

Interogrator.In the navigation system we must understand the working principles of the system VOR (Very high Omnidirectional Range), DME (Distance Measuring Equipment) and ILS (Instrument Landing System). The three systems are used by pilots during flight and landing 
process

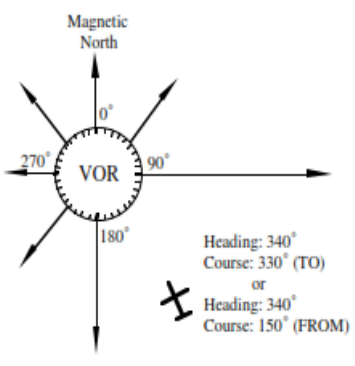

(A) VOR Station

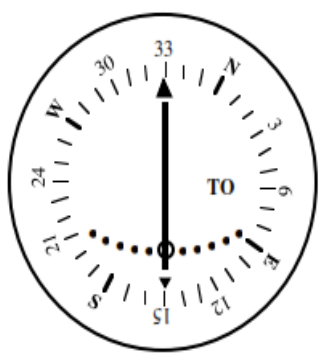

(B) VOR Indicator
Figure 2. VOR

VOR is an operating facility working on VHF frequencies at a frequency range of 108-118 $\mathrm{MHz}$ with a reference signal difference of $30 \mathrm{~Hz}$. Where the transmit distance is limited to 200 NM (nautical mile).

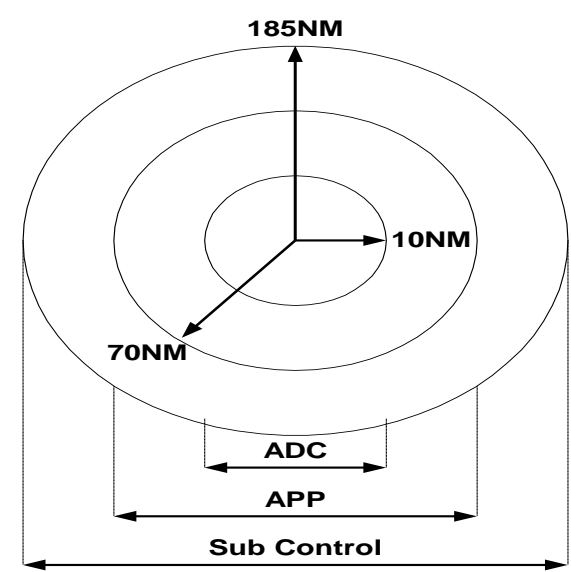

Figure 3. The division of the aircraft setting area.

With the VOR on the aircraft and the information guide from the airport then the plane will know the position of the plane with the flight runway, so it can make a perfect landing.

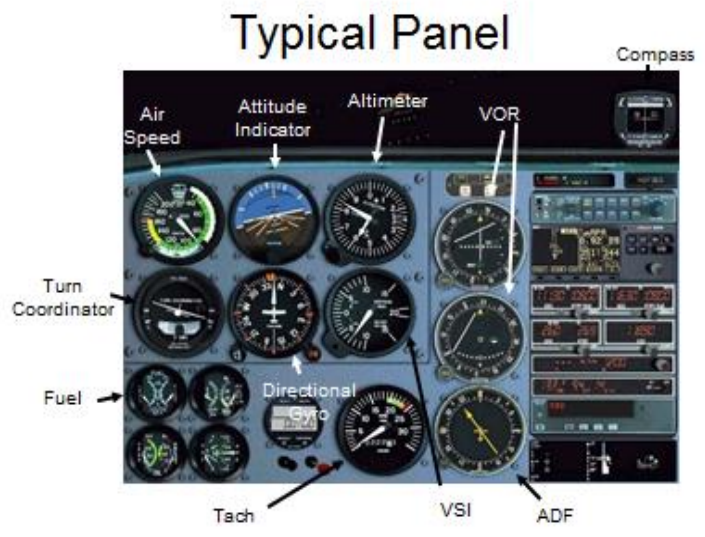

Figure 4. ILS system in plane.

ILS is an instrument used to assist in the landing process due to its limited capabilities. In landing the aircraft requires 3 supporting conditions: landing angle (Glide Angle), Center Line of Runway and touch point of landing. In ILS there is an altimeter that can be used to determine the height of the aircraft while in the air

\subsection{Infrastructure Radar.}

Since Radar is an important tool in the world of navigation, military, astronomy and communications, the construction of radar infrastructure is a matter of concern. In radar infrastructure things to watch out for in development are Tower, Voltage, Lightning Protection

a.Tower

Tower is a place used to install a radar. In some places the towers are built high to cover large areas and for the electromagnetic waves of radar to be transmitted directly. for 
high places are usually tower in pairs of randome that serves to protect the radar from lightning

\section{b.VoltageGenerator}

A stable power supply is necessary in the operation of a radar. Because in the operation of the radar system should not die and must work full 24 hours. If there is a blackout of electricity supply from PLN then the existing voltage generator must be able to supply the electricity needs radar system. C. Communications and networking. A permanent communication and network system between the radar system and the operating center is needed to create system reliability. Fiber optic, satellite, microwave data lines, copper cables is one option in communicating.
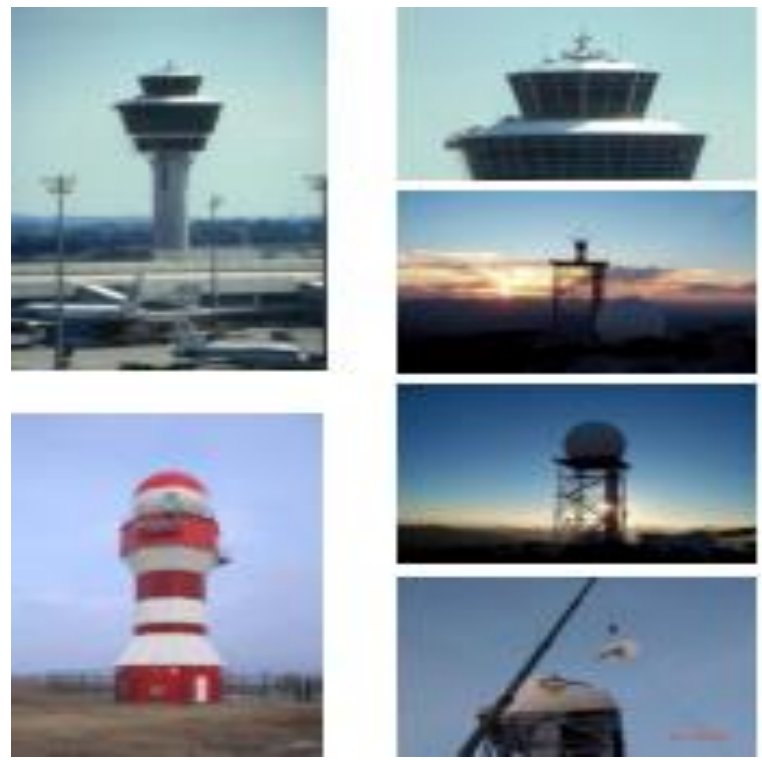

Figure 5. Various examples of tower and random Infrastructure

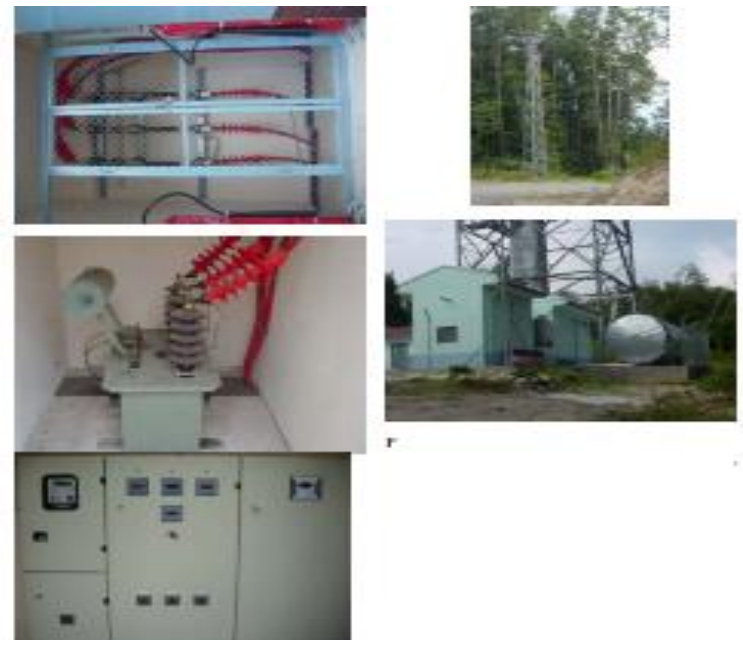

Figure 6 Back-up power supply.

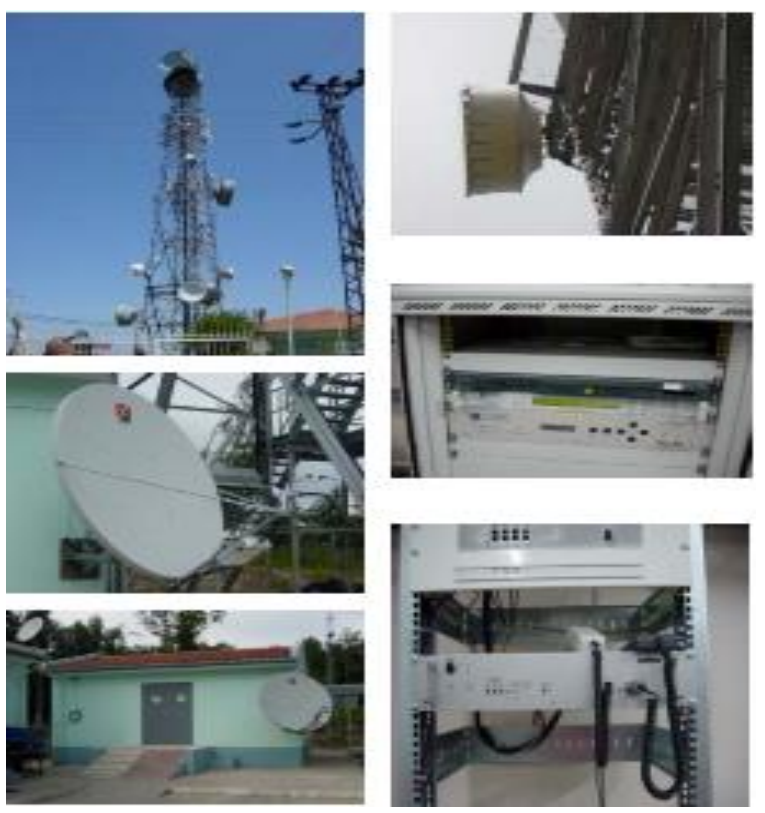

Figure 7. Communication tools that support the radar system ..

\subsection{Hardware Radar}

In general a radar contains transmitters that produce microwave signals. This signal is sent to free space via antenna transmitter. If exposed to an object this signal will be connected to the radar (echo). A receiver will 
detect and process the signal received by the radar through the processor signal radar and then on if and the results can be displayed in the form of graphics and images. This process can be seen in Figure 8.

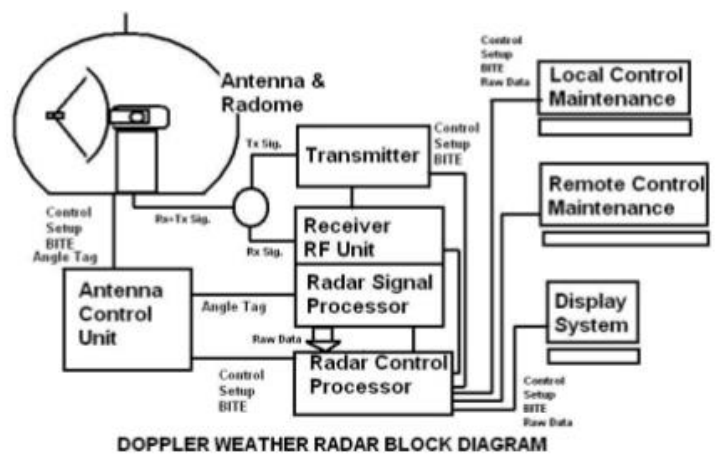

Figure 8. Common block diagram of weather radar.

To generate power gain on a radar usually use a Klytron tube or a magnetron tube. Where this tube can produce large power outputs up to 10 KW with small power input.

\subsection{Radar Maintenance and Calibration}

\section{Techniques}

Maintenance and calibration of the radar system is one of the important aspects in operating radar network in order to remain efficient and the availability of data that has high quality. Maintenance and calibration can be done by the institution / organization of users of radar system or can be done by outsiders (private) arranged in the contract work.
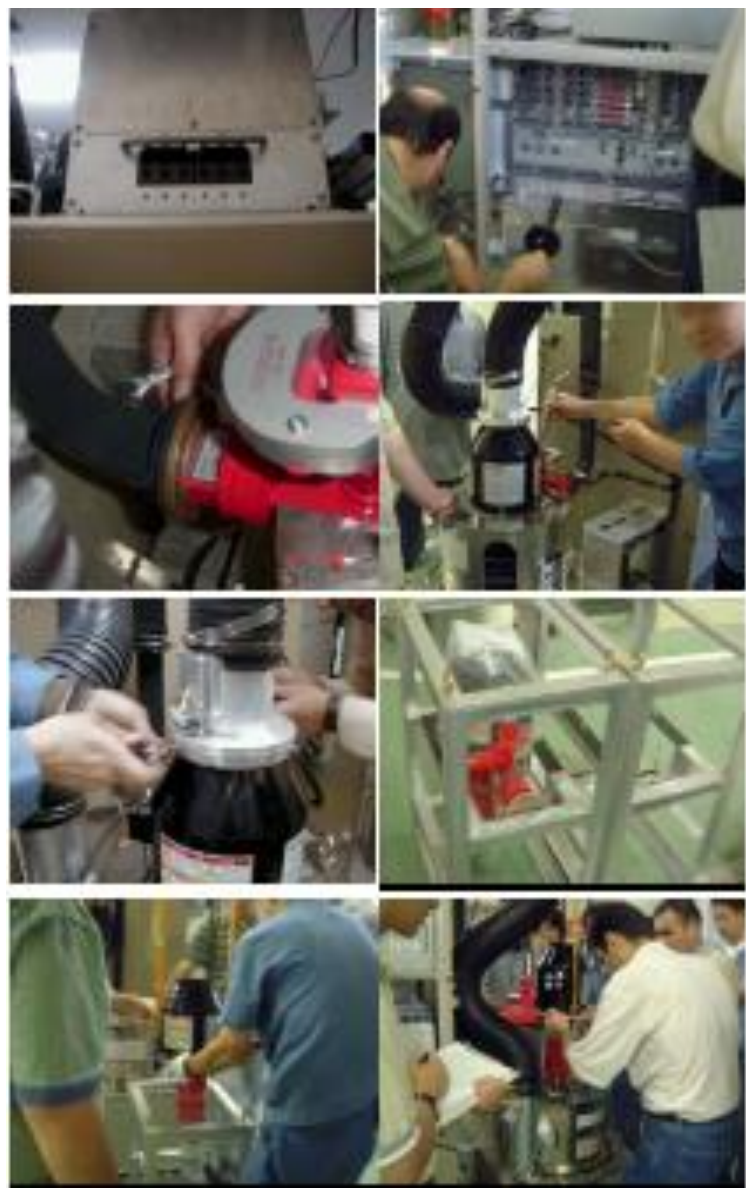

Figure 9: Klystron change process

\section{RESEARCH METHOD}

The research that will be carried out is research based on the development of teaching module of Telecommunication Teaching course. The research method that will be used is kind of method of research and development of R \& D. states that research and development, is a research method used to develop or validate the products used in education and learning. Further, according to Seels \& Richey in (Mursid, 2013: 30) explains that development research is a systematic study of designing, evaluating development, teaching programs, processes and 
products that must meet internal consistency criteria and effectiveness. This research development of teaching module is done in Electrical Engineering Department of State University of Surabaya and the time of research implementation in Odd Semester of academic year 2016-2017. The research population of the development of this teaching module is a student of Electrical Engineering Education S1 2014 at the Department of Electrical Engineering, State University of Surabaya. The sample of this research is the students of electrical engineering education at the Department of Electrical Engineering, Universitas Negeri Surabaya in the academic year 2016-2017

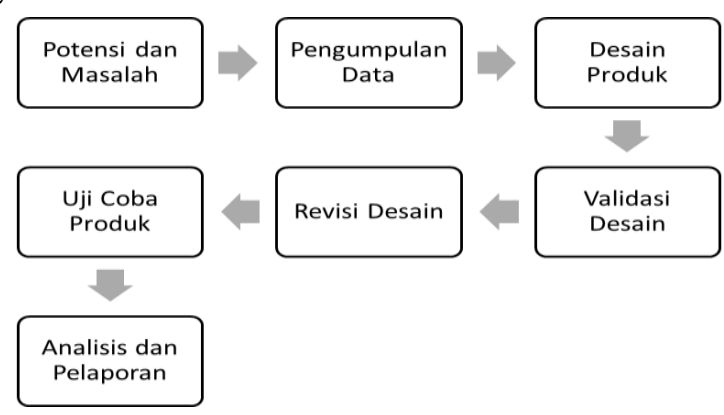

Figure 10. Block diagram of research and development steps

Gambar diatas merupakan prosedur atau langkah yang akan digunakan dalam penelitian yang dimodifikasi dari metode research and development.

\section{PENGUJIAN DAN PEMBAHASAN}

Berdasarkan pada metode dan instrumen penelitian, teknik pengumpulan data yang digunakan oleh peneliti adalah dengan menggunakan penggunaan kuisioner atau angket dan di validasi oleh dosen ahli. Teknik analisis data untuk mengukur validitas variabel yang berupa instrumen angket atau lembar validasi pada instrumen penelitian ini adalah dengan menggunakan analisis deskriptif untuk membaca hasil rating scale pada hasil angket tersebut. Penilaian rating scale tersebut menggunakan skala Likert.

Table 1. Category Validation Value, Effectiveness, and Response to Teaching Module

\begin{tabular}{lllc}
\hline $\begin{array}{l}\text { Penilaian } \\
\text { Kualitatif } \\
\text { Validator }\end{array}$ & $\begin{array}{c}\text { Penilaian } \\
\text { Kulitatif } \\
\text { Efektifitas Media }\end{array}$ & $\begin{array}{c}\text { Penilaian } \\
\text { Kualitatif } \\
\text { Respon } \\
\text { Mahasiswa }\end{array}$ & Kategori skor \\
\hline Sangat valid & Sangat Efektif & Sangat baik & $76 \%-100 \%$ \\
Valid & Efektif & Baik & $51 \%-75 \%$ \\
Kurang valid & Kurang Efektif & Kurang Baik & $26 \%-50 \%$ \\
Tidak valid & Tidak Efektif & Tidak baik & $0 \%-25 \%$ \\
\hline
\end{tabular}

Based on the Validation Results by media experts, module validation results can be obtained from several aspects with details: 1) The teaching module material gets an average of $85 \%$; 2) The presentation of the teaching module gets an average of $87.5 \%$; 3) Language and readability got an average of $82.5 \%$. ; 4) The general display gets an average of 81.25 So the overall result of module validation according to the media expert seen from the four aspects above are: $336.25 \%$ / $4=84.06 \%$ Thus the module designed for the course of Radar and Navigation is valid is valid according to the media expert with the result of the rating of $84.06 \%$, so that the learning module developed by the researcher can be used as a learning module at Universitas Negeri Surabaya. Based on the results of the student response 
questionnaire can be seen the acquisition of module validation results seen from several aspects with details: 1) Cover got an average of $83.3 \%$; 2) illustration gets an average of $83.75 \%$;

3) Language gets an average of $82.5 \%$. ; 4) the contents got an average of $83.3 \%$

So the overall result of questionnaire module according to student response seen from four aspect above is: $332.85 \% / 4=83.21 \%$. Thus the module designed for the course of Radar and Navigation is believed to be very valid according to the media expert with the result of the rating of $83.21 \%$, so that the learning module developed by the researcher can be accepted by the students of electrical engineering education that follow the radar and navigation courses.

\section{V.Conclusion}

This research produces the product in the form of teaching module which can be used as one of reverensi in radar learning process and navigation. Instrument researchers used as a learning medium is a teaching module, module validation sheet teaching and student response questionnaire.

Based on the data of research results and discussion it can be set up as follows: 1. Based on the validation result of the development of the radar and navigation module by the validator, this module is categorized well and feasible to use with the average of $84,06 \%$. 2. Assessment of student response to the development of radar and navigation module received a positive response with an average value of $83.21 \%$ and categorized well

\subsection{Suggestions}

Based on the research stage that has been done then the suggestions that can be given are as follows:

1. This research is only researching the feasibility of developing teaching module, so that the making of radar props to support student lectures have not been made. 2. The development of media trainers in the form of radar can be developed with the help of ultra sonic sensors, arduino uno so that students can study the real rational working principle, which can be developed in subsequent research.

\section{REFERENSI}

[1] Training Material on Weather Radar System" oleh Dr. R.P Cantherford

[2] Radar Level Measurement" oleh Peter Devin. 